\title{
Criteria for Choosing the Priorities of Smart Development of Industrial Centers in the Context of Globalization
}

\author{
Volodymyr Rodchenko ${ }^{1 *}$, Jiafei Guo ${ }^{2}$, Yuliia Prus $^{1}$, Liu Zeyu ${ }^{2}$ \\ ${ }^{1}$ V. N. Karazin Kharkiv National University, 4 Svobody Sq., Kharkiv, 61022, Ukraine \\ ${ }^{2}$ Luoyang Normal University, Guangwen Rd, Jianxi Qu, Luoyang Shi, Henan Sheng, 471132, China
}

\begin{abstract}
The purpose of the study is to justify the criteria for choosing the priorities of a smart development of industrial centers in the context of globalization. By analyzing, systematizing and summarizing scientific works, it has been determined that the process of globalization has gone so far that even economically developed countries cannot independently solve production, scientific, technical, financial, trade and other problems effectively. The time of separate and independent economies is over. Industrial centers are the generators and re-translators of global change, the "backbone" of the world economy. In the course of the study, using a structural approach, the authors proposed five groups to assess the components of the potential and the prospects for the smart development of industrial centers in the context of globalization.
\end{abstract}

In the last decade, one of the most important factors in a world development has been the phenomenon of globalization, which covers not only the economy and sphere of entrepreneurial activity, but also the political and social sphere. The concept of "globalization" was introduced into a broad scientific revolution in the late 1980s and early 1990s. The first author who used this term was the American scientist T. Levit, who in 1983 in Harvard Business Review's article wrote about the merger of the markets of individual products produced by large multinational corporations [1].

To date, the process of globalization has gone so far that even economically developed countries cannot independently solve production, scientific, technical, financial, trade and other problems effectively. The time of separate and independent economies is over. Predicting the future, scientists point view to the inevitable formation of the economy of the planet, where national economies will become part of a certain whole system. Globalization is interpreted by science as objective data, which simply cannot be reckoned with. Objective means that isolation, exclusion and insularity are the direct path to the loss of economic benefits, backwardness and non-competitiveness.

World experience has shown that industrial centers are the generators and re-translators of global change, the "backbone" of the world economy. These are modern global industrial centers (which are the peaks of the global geopolitical and geo-economic landscape), and

\footnotetext{
* Corresponding author: rodchenko@karazin.ua
} 
dozens of other industrial centers that are only approaching the upper levels of the hierarchy. At the same time, the industrial center is the recipient of global change with all the threats and benefits. Given the public significance of the industrial center as a widespread habitat (since 2007, more than half of the world's population live in industrial centers) and the potential problem of such intensive urbanization (by 2050 , about $80 \%$ of the world's urban population will live in developing regions, especially in the cities of Africa and Asia), the relevance of research in this area is undoubted.

The development of industrial centers in a new global environment is studied by scientists from various fields of activity, since it is the industrial centers that serve as the main places of globalization. For example, F. Erixon considers the industrial centers as peculiar "gateways to the global world" and emphasizes the uneven spread of globalization [2]. P. Samimi analyzes the process of increasing competition between regions and industrial centers, defines approaches to the management of the development of industrial centers, trends and processes caused by globalization in her works [3]. In other works, industrial centers are considered in the context of sustainable development [4] and the level of globalization [5].

In the leading scientific schools, the tradition of studying global industrial centers has existed for several decades with dozens of major scientific programs and projects. Instead, the Ukrainian scientific schools of the regional economy have insufficient studies on the issue of patterns and trends shaping and development of the industrial centers of Ukraine under globalization. In connection with the foregoing, the purpose of the study is to justify the criteria for choosing the priorities for the smart development of industrial centers in a globalizing environment.

To date, a new hierarchy of industrial centers has been formed: that ones that have focus on new functions are growing faster. Some industrial centers, being components of global economic networks, receive the bulk of the rent from the spread of innovations. Globalization is an innovation process. Innovative impulses originate in the most advanced industrial centers, leading in the development and development of new technologies with financial resources and highly skilled personnel.

Determining the criteria for choosing the priorities for smart development is controversial. The idea of the impossibility of choosing a single criterion basis and the existence of an "own way" of choosing a strategy for smart development prevails for every industrial center. At the same time, the structural proportions considered in different sections can form the starting positions for choosing priorities.

In order to choose the criteria for the smart development of industrial centers in a globalized environment, it is appropriate to use the simplest approaches to assessing the level of concentration of business entities in a particular market (Herfindahl-Hirschman index, Hall-Taydman index, etc.).

For example, the US Department of Justice determines the degree of concentration of the market by the Herfindahl-Hirschman index, guided by the following scale [6]:

- index is below 0.1 - a slight concentration of the market;

- index is from 0.1 to 0.18 - an average market concentration;

- index is above the 0.18 - a high concentration of the market.

In the United States any association of industrial centers that increases the HerfindahlHirschman index by 0.1 points (or 100 points) in the average concentration market (and by $0.05 / 50$ points in the high-concentrated market) automatically leads to application of antimonopoly legislation [6].

When substantiating the criteria for choosing the priorities for the smart development of industrial centers, the most informative indicator is gross added value. It is a direct source of the welfare of the industrial center. However, in the current statistical base, its calculation and selection at the level of industrial centers is extremely complex. Therefore, 
it is suggested to use the gross output indicator for the analysis, although the gross value added is more meaningful and indicative.

Structural indicators are fundamental in the methodology of the selection of smart strategy specialization by European Commission (RIS 3) [7]. The main criteria for choosing the priority sectors (types of economic activities) that can ensure the positive dynamics of the industrial centers development are: indicators of the relative share of output, number of employees, volume of exports, number of patents of a possible priority type of economic activity in the total volume of relevant indicators of the industrial center. The dominance of the specific weight of an economic activity by the above indicators allows us to determine the prospects of industry specialization.

In order to diagnose the priority areas of smart development, it is advisable to use a structural approach that allows to determine and compare different sections of the activity of industrial centers. The improvement of existing approaches and their adaptation to the specifics of the industrial centers development can be proposed by the following five groups of indicators for the assessment of potential components and prospects for smart development:

I. Indicators of the internal technological structure:

1. Structural proportions of the industrial centers gross output by types of economic activity. It is advisable to consider the types of economic activity with the most accessible level of detail. According to the authors, it is acceptable to detail at the level of the second mark of the Classification of Types of Economic Activity. In assessing this indicator, the absence of types of economic activity, whose share exceeds a third of the total volume of gross output, should be considered as positive. Also, a situation of high concentration, when three or less types of economic activity form more than half of the gross output of the industrial center, can be threatening. The assessment of this indicator will help to determine the level of sectorial structure and form the basis for concluding that there is a need to support new types of activities or existing production proportions. As examples, the scenario of the development of industrial centers with imperfect structural proportions of the output can include scenarios for the development of the Detroit city (USA), oneindustry towns in eastern Ukraine, and others.

2. Structural proportions of output by types of economic activity, grouped by type of technological processes. The dominance in the total volume of production of certain technological processes allows us to determine the level of "technological age" of the industrial center, and, accordingly, to form conclusions about the urgency of the need for a transition to a higher technological level. This indicator will allow us to formulate judgments about the acceptability of an evolutionary, modernizing or hopping trajectory for the industrial center development. An in-depth analysis of this indicator, combined with an analysis of the main factors of the potential for the industrial center development, provides the basis for discussion on the choice of development path.

II Indicators of the export (import) specialization of the industrial center:

1. Structural proportions of the product export (import) of industrial centers by the economic activity types. The experience of developed industrial centers shows that the optimal conditions of effective foreign economic activity is importing raw materials and exporting finished products, providing more volume of added value.

For example, today, according to experts' estimates, more than $50 \%$ of Ukrainian exports are products with low value added. The annual volume of exports is about $\$ 50$ billion. Only agrarian products with low added value in 2018 Ukraine were exported in the amount of $\$ 19$ billion. Assuming that raw materials export $-50 \%$, which gives a multiple increase in value added, the Ukrainian economy loses about \$25 billion [8].

Importance in the development of industrial centers is inclusiveness in global value added chains. They are characterized by a network type of organization, by the complexity 
and diversity of development. Under such conditions, the indicators of structural proportions are not enough informative and do not give the desired result. To diagnose global value creation chains, it is appropriate to use big data. Being apart from the large array of statistical information (which access in Ukraine is limited), it is necessary to take into account the information that characterizes the inclusion of industrial centers into clusters, which parts of the value-adding chains bring the greatest profit, possible exchange of resources between traditional chains creation of value and those at the stage of formation.

III Indicators of the intellectual capital of the industrial center:

1. Age structure of the employed population in industrial centers by types of economic activity. This indicator shows the perception of the population by innovations. The smart industrial centers development underlies this. It has been scientifically proven that there is a reciprocal correlation relationship between the age of a person and their propensity to accept innovations. As a rule, young people are ready to experiment freely. They are more likely to learn something new and easily perceive innovations, while older generations give up the advantage of a well-established business model and, in most cases, are unwilling to accept innovation.

Confirming this, the president of the National Academy of Educational Sciences of Ukraine V.G. Kremen emphasizes that only by forming an innovative person capable of creating change and perceptions of change, we can become a competitive nation. Because the variability, transformation ceases to be an exception, but becomes the rule, an essential feature of the functioning of society and every member of the XXI century. In this regard, Ukrainian society should prepare a person for life in new conditions, to form an innovative person [9].

2. Structural proportions of patents' concentration for inventions in industrial centers by types of economic activity. In modern economic conditions, a patent portfolio is considered as an asset of an industrial center that can be used for various tasks.

For example, in 2012 the Ukrainian startup Viewdle was sold to Google for more than $\$ 30$ million. At the time of sale, Viewdle has filed 11 patents in the United States. Another case is Looksery, which Snapchat bought for $\$ 150$ million in 2015. Looksery had 4 patents for inventions and 15 patents applications in the US [10].

It should be noted that patenting is also beneficial to the state, since for the registration of each patent the inventor or the enterprise pay the State Service of Intellectual Property.

The concentration of patents is one of the competitive advantages of industrial centers; however, for their effective implementation, it is necessary to develop a developed infrastructure that will allow early inventions to be turned into finished products, as well as increase the security of business.

3. The ratio of structural proportions of the number of employed population and the amount of wage payments in the industrial centers by types of economic activity. It is extremely important in every industrial center to achieve a balance between these two indicators. Since in most cases most of the population of the country employs certain types of economic activity, while the largest amounts of wage payments are accumulated in other areas. This increases the gap between the individual strata of society and, accordingly, exacerbates the level of social tension.

For example, by 2017, the largest number of Ukrainians are employed in wholesale and retail trade $(21.8 \%)$, agriculture $(17.7 \%)$ and industry $(15.1 \%)$, while the largest volume of wages is typical for industry (25.8\%), education (14.9\%) and public administration and defense $(9.8 \%)$ [11].

IV. Indicators of the structure of investment flows of the industrial center:

1. Structural proportions of volumes of capital investments in the industrial centers by types of economic activity. The ratio in the structure of capital investments 
in the development of active (machinery, equipment etc.) and passive (building, construction etc.) fixed assets is an indicator of the availability of additional funds in industrial centers to expand the scope of activity and the level of resistance to innovation. As a rule, at the stage of product output and growth of the industrial center, the share of investments, which is directed to the expansion of the active part of the funds due to the limited funds, increases. At the stage of maturity, the share of investments in the expansion of the passive part of funds increases.

2. Structural proportions of investments in industrial centers by sources of financing. For effective functioning of the industrial center it is important to determine the real need for financial resources, the optimal structure of the sources of their formation. The prevalence in the structure of industrial investment center's own funds is a testament to the closure of industries. This is typical for the crisis or high-risk environments, while the involvement of credit are for the introduction of intensive development model.

$\mathrm{V}$. Indices of the structural dynamics of the industrial center:

1. Structural proportions of dynamics of output volumes in the industrial centers by economic activity types. To compare the obtained values as a benchmark criterion, it is appropriate to use indicators of the dynamics of the national economy. For the products that are in the introduction stages of the life cycle (launch to the market) or growth, the growth rate of production will be higher than the growth rate of the economy. For the products in the stage of maturity, the growth rates of output are stable and are in a range close to the rate of economic growth. For the products in the downturn phase, slowdowns are characteristic, which, respectively, are lower than the growth rate of the economy.

The proposed set of indicators forms a methodological basis for identifying the priority directions of the industrial centers development. The main target orientations are:

- destimulation of raw exportation and outsourcing service models and localization of raw material processing chains;

- diversification of the economy and transformation of rental models of the industrial center functioning;

- restriction of adsorption of obsolete technologies and prevention of technological lagging preservation. The main benchmark is the best available technology solutions;

- provision of optimal age structure of personnel capital, including through replacement of non-competitive workplaces with technological equipment;

- possibilities of increasing the effective human capital through mechanisms of remuneration of workers from economically unproductive spheres and from the outside;

- the replacement of the paternalistic outlook and the full support of entrepreneurial initiatives.

Crisis manifestations in the dynamics of the global situation determine the relevance of the decentralization of the management national models in the economic development processes in the context of targeting inclusion into the global value added chains. In such conditions, the implementation of an adequate approach for a smart strategic choice of the priorities of the industrial centers development becomes a special role. The program approach, which usually ensures the effectiveness of such a choice, is not sufficiently effective. This results to the transfer of the center from the national to the local level and the corresponding change in the methodological apparatus and the target guidelines for choosing the strategic development of the industrial centers. 


\section{References:}

1. Levitt T., Harvard Business Review, Autumn (Fall), 92 (1983).

2. Erixon F., European centre for international political economy, 21 (2018).

3. Shangquan G., Economic \& Social Affairs, 1, 10 (2000).

4. Samimi P., Journals PLoS One, April (2014).

5. Lascurain Fernández, M. Revista de Relaciones Internacionales, Estrategia y Seguridad, 12(1), 23 (2016).

6. Barr W., The United States Department of Justice (2018).

7. Guide to Research and Innovation Strategies for Smart Specialisation (RIS3). URL : $\quad$ http://ec.europa.eu/regional policy/sources/docgener/presenta /smart specialisation/ smart ris3 2012.pdf.

8. Amelin A., Ukrainian Institute for the Future. URL: https://www.uifuture.org/publications/news/24557-amelin-polovuny-ekonomikydaruyemo-svitu.

9. Kremen V., Education and development of gifted personality, 8-9, 7 (2013).

10. Mishchenko T., Snapchat bought for $\$ 150$ million Ukrainian startup Looksery. URL: https://itc.ua/news/snapchat-kupil-za-150-mln-ukrainskiy-startap-looksery/. 